\title{
Artificial Intelligence in Business
}

\author{
Amandeep Kaur ${ }^{\mathrm{a}, \mathrm{I}}$, Anjum Mohammad Aslam ${ }^{\mathrm{b}}$ \\ amehako7@gmail.com ${ }^{\mathrm{a}}$, anjumcse.I8@gmail.com ${ }^{\mathrm{b}}$ \\ Department of Computer Science $\&$ Engineering, Chandigarh University, \\ Mohali, Punjab $^{\mathrm{I}}$
}

\section{Abstract}

In this chapter we discuss the core concept of Artificial Intelligence. We define the term of Artificial Intelligence and its interconnected terms such as Machine learning, deep learning, Neural Networks. We describe the concept with the perspective of its usage in the area of business. We further analyze various applications and case studies which can be achieved using Artificial Intelligence and its sub fields. In the area of business already numerous Artificial Intelligence applications are being utilized and will be expected to be utilized more in the future where machines will improve the Artificial Intelligence, Natural language processing, Machine learning abilities of humans in various zones.

Keywords Artificial Intelligence, Natural language processing, Machine Learning, Neural Network, Deep Learning, Business Models

\section{A. Introduction}

Artificial intelligence is the broad branch of Computer Science which is the most powerful and important technology innovation of all times. During the nineteenth century, 
This is a limited preview of the chapter.

To read the full-text chapter, get access by purchasing this chapter or consider buying the complete book. If your library has subscription to EBSCOhost, the chapter including other chapters of the book can be accessed through your library.

This chapter is a part of the book, 'Management of Data in AI Age' ISBN (paperback): 978-8I-948483-4־9; ISBN (ebook): 978-8I$948483-5-6$

Book DOI: https://dx.doi.org/Io.46679/isbn9788194848349 Chapter DOI: https://dx.doi.org/I0.46679/isbn9788I94848349oI 
To capitalize on AI technology, businesses will need to hire people with AI experience or the skills to analyze and use the data to encapsulate need of human supervision with AI. Businesses also need the computing power and system infrastructure to support AI-enabled products and services, and they need platforms to organize and integrate their data. Getting this infrastructure in place can be expensive.

Moreover, the data collected by AI offers another big challenge. How do businesses guarantee the validity of data collected in terms of correctness and reliability? What limits do they need to put on its use? Confirmation of the fact, that machine will carry out human orders as intended?

There are concerns that unintentional biases may find their way into $\mathrm{AI}$ algorithms or decision-making models. Businesses need to establish robust controls to prevent this from happening and monitor the systems that learn through AI. Letting stakeholders know about the business's oversight can help establish trust with stakeholders that businesses are using AI reliably.

\section{References:}

[1] Akerkar, R.(20I9). Artificial Intelligence for Business, Springer Briefs in Business, pp. I-92. Springer, Cham, https://doi.org/I0.1007/978-3-319-97436-I

[2] Aslam M. A., Kaur. A.,(2020). Emerging Trends and Applications of Machine Learning: A Survey, The Mattingley Publishing Co Inc., Vol. 82, I670I-16705. 
[3] BaFin (2018). Big Data Meets Artificial IntelligenceChallenges and Implications for the Supervision and Regulation of Financial Services.

https://www.bafin.de/SharedDocs/Downloads/EN/dl_bdai_st udie_en.html (accessed on 30/5/2020).

[4] Dara, H.,Chowdary, R. छ Kumar, C. (2019). A survey on group recommender systems. Journal of Intelligent Information Systems. 10.1007/sio844-018-0542-3.

[5] Das, S., Ghosh, I., Banerjee, G. छ̋ Sarkar, U. (2018). Artificial Intelligence in Agriculture: A Literature Survey. International Journal of Scientific Research in Computer Science Applications and Management Studies, Volume 7, Issue 3

[6] Finlay, S. (2018). Artificial Intelligence and Machine Learning for Business: A No-Nonsense Guide to Data Driven Technologies (Third Edition). Relativistic, ISBN-I3: 9781999730345.

[7] Gartner.(2019). Gartner Says AI Augmentation Will Create \$2.9 Trillion of Business Value in 2021.

https://www.gartner.com/en/newsroom/press-releases/20I9-08, o5-gartner-says-ai-augmentation-will-create-2pointg-trillion-ofbusiness-value-in-202I (accessed on $30^{\text {th }}$ May 2020).

[8] Girasa R. (2020) AI as a Disruptive Technology, Springer Science and Business Media LLC, DOI https://doi.org/I0.1007/978-3-030-35975'I_I

[9] Kim, H.N., \& El Saddik, A. (20I5). A stochastic approach to group recommendations in social media systems. Information Systems, 50(Supplement C), 76-93.

[10] Kim, J.K., Kim, H.K., Oh, H.Y., Ryu, Y.U. (2010). A group recommendation system for online communities. International Journal of Information Management, 30(3), 2I2-2I9.

[11] Krishnan, P.R.(2019), Reshaping a Business Around AI: The Machine First ${ }^{T M}$ Approach to Digital Transformation. https://www.tcs.com/content/dam/tcs/pdf/perspectives/volum e-I2/Reshaping-a-Business-Around-AI-The-Machine-FirstApproach-to-Digital-Transformation.pdf (accessed on $30^{\text {th }}$ May 2020). 
[12] Management Solutions (2018), Machine learning a key component in business model transformation, https://www.managementsolutions.com/sites/default/files/publ icaciones/eng/machine-learning.pdf (accessed on $30^{\text {th }}$ May 2020).

[13] MEMSQL, Survey Finds Machine Learning and Artificial Intelligence are Top Business Priorities, https://www.globenewswire.com/newsrelease/2018/02/07/1335563/0/en/Survey-Finds-MachineLearning-and-Artificial-Intelligence-are-Top-BusinessPriorities.html (accessed on $30^{\text {th }}$ May 2020).

[14] Minsky M.(I96I). Steps toward artificial intelligence. Proceedings of IRE, Vol. 49, no. I, pages 8-30.IEEE

[15] MobiDev (20I9). Natural Language Processing (NLP) Use Cases for Business Optimization.

https://mobidev.biz/blog/natural-language-processing-nlp-usecases-business (accessed on $30^{\text {th }}$ May 2020).

[16] O'Leary,D.E. (I995), On the History of the AI Applications, I: IEEE Expert, the First Nine Years, IEEE Expert, Vol. Io, No. I, https://doi.org/Io.IIo9/64.391956

[17] Pau L.F., Gianotti C. (I990) Applications of Artificial Intelligence in banking, financial services and economics. In: Economic and Financial Knowledge-Based Processing. Springer, Berlin, Heidelberg, ISBN : 978-3-642-76004-4.

[18] $\mathrm{PwC}$ (2018). 20I8 AI predictions - 8 insights to shape business strategy.

https://www.pwc.es/es/publicaciones/tecnologia/assets/aipredictions-20I8.pdf (accessed on $30^{\text {th }}$ May 2020).

[19] Rong, G., Mendez, A., Bou Assi, E., Zhao, B. छ Sawan, M. (2020). Artificial Intelligence in Healthcare: Review and Prediction Case Studies. Engineering. Volume 6, Issue 3, Pages 29I-3OI.

[20] Satista. (2020), Natural Language Processing market revenue worldwide 2017 - 2025, https://www.statista.com/statistics/60789I/worldwide-naturallanguage-processing-market-revenues/\#statisticContainer (accessed on $30^{\text {th }}$ May 2020). 
[21] Soofastaei, A. (2019). Introductory Chapter: Advanced Analytics and Artificial Intelligence Applications, IntechOpen, DOI: 10.5772/intechopen.89784

[22] UpGrad (2019), 5 Applications of Natural Language Processing for Businesses. https://www.upgrad.com/blog/5 applications-ofnatural-language-processing-for-businesses/ (accessed on $30^{\text {th }}$ May 2020).

[23] Zirra.(20I7). o Tools that Simplify Competitive Analysis (20I7). https://wisdom.zirra.com/20I7/08/24/9-tools-that-simplify, competitive-analysis/ (accessed on $30^{\text {th }}$ May 2020). 